\author{
Tetyana Rudenchyk, Rita Rozhnova, Volodymyr Shtompel, \\ Natalia Galatenko and Svitlana 0 stapuk
}

\title{
RESEARCH ON BIODEGRADATION OF EPOXY-POLYURETHANE COM POSITES FILLED WITH FERROCENE IN THE MODEL BIOLOGICAL MEDIUM
}

\author{
Institute of M acromolecular Chemistry of the National Academy of Sciences of Ukraine \\ 48 Kharkivske Ave., 02160 Kyiv, Ukraine; Rudenchyk@yandex.ua
}

Received: August 19, 2013 / Revised: October 25, 2013 / Accepted: M arch 23, 2014

(C) Rudenchyk T., Rozhnova R., Shtompel V., Galatenko N., Ostapuk S., 2015

\begin{abstract}
The influence of model biological medium on the properties and structure of epoxy-polyurethane (EPU) ferrocene compositions has been investigated by physicalmechanical IR-spectroscopic and X-ray methods. It has been established that the EPU compositions biodegrade most intensively after 1 month of incubation, accompanied by a decline in strength at $80-92 \%$ break. According to the IR-spectroscopic studies biodegradation occurs by ester and to a greater extent ether linkages with simultaneous redistribution of hydrogen bonds system, which is associated with structuring of polymer compositions in model biological medium 199 (BM 199). The relaxing nature of structure formation processes in the volume of polymer composites under the influence of BM 199 has been confirmed. According to small-angle X-ray diffraction upon exposure of sample EPU (10.0F) during 6 months in BM 199 the rise of similar microareas of heterogeneity is observed, which may be the result of specific interaction of molecules of enzymes that are presented in BM 199 with urethane and amide EPU groups.
\end{abstract}

Keywords: epoxy-polyurethane, composite materials, ferrocene, biodegradation.

\section{Introduction}

Epoxy-polyurethane (EPU) compositions are promising for obtaining medical supplies. It is proposed to use them as plates for osteosynthesis in maxillofacial surgery [1-4], plasty of bone defects formed as a result of tuberculosis of bones [5]. Epoxy component of such compositions results in high physical-mechanical properties of the material while the polyurethane component provides elasticity and enhances biocompatibility.
Previously [6] we have synthesized and investigated the properties of several fumarate-containing EPU for different filling of ferrocene - metal complex sandwich biologically active compound. Since the results of biomedical testing of these composites showed biocompatibility and bioactivity it was proposed to use them as bioactive bone implants [7].

One of the necessary steps in creating biologically active composite materials intended for use as implants is the study of biodegradation under conditions close to the medium of the human body.

Today, not only the basic mechanisms and ways of biodegradation of polyurethanes, including reticulum polyurethane are established but some factors that influence the course of this process in vivo are also identified [8]. These include the chemical nature of the polymer, the spatial structure of the polymer molecules, hydrophilicity, cross-linking density, supramolecular structure of the polymer, etc. Since under the condition of implantation of the polymer material the changes in its structure occurs, including the supermolecular level, accompanied by change of many properties, it made sense to investigate the effect of BM 199 on the structure and properties of EPU filled with ferrocene. The results obtained in vitro in combination with the results of experimental studies on animals will allow predicting the "behavior" of these composite materials when used as implants.

The purpose of this study is to investigate the biodegradation of EPU composites filled with ferrocene by the change in their physical-mechanical properties and structure under the influence of BM 199 using physicalmechanical, IR-spectroscopic, and X-ray diffraction analysis methods. 


\section{Experimental}

\subsection{M aterials}

We investigated EPU samples and compositions EPU(0.1F), EPU(1.0F), EPU(3.0F), EPU(5.0F), $\mathrm{EPU}(10.0 \mathrm{~F})$ on its basis filled with $0.1,1.0,3.0,5.0$, and $10.0 \mathrm{wt} \%$ of ferrocene, respectively.

BM 199 was used as a model medium, which imitates the blood plasma, which is a complex mixture of proteins, amino acids, carbohydrates, fats, salts, hormones, enzymes, and soluble gases $(\mathrm{pH}=7.4)$ [9].

\subsection{M ethods}

EPU composite materials were obtained by reaction of isocyanate prepolymer (IPP) (based on oligooxypropylene fumarate $(\mathrm{MM}=2600), 2,4-, 2,6-$ toluylene diisocyanate (TDI 80/20) with epoxy resin ED20 for the molar ratio of ED-20: IPP $=6: 1$ (conversion of NCO groups $\sim 67.8 \%$ ), followed by addition of the calculated amount of 1,4-butanediol. The reaction was carried out at the temperature of $348 \pm 5 \mathrm{~K}$ up to complete conversion of isocyanate groups. Ferrocene in the amount of $0.1-10.0 \mathrm{wt} \%$ was inserted into the polymer matrix in $30 \%$-term solution of $\mathrm{N}, \mathrm{N}$-dimethylacetamide. Curing was performed using amine hardener L-20 [6].

Samples of composites in the form of $0.5 \times 5.0 \mathrm{~cm}^{2}$ strips were incubated in BM 199. The samples were placed in sterile weighting cups of $25 \mathrm{ml} \mathrm{BM} 199$ and kept in the incubator at the temperature of $310 \pm 1 \mathrm{~K}$ for the period of 1,3 , and 6 months, after which they were taken out, washed with distilled water and dried to constant weight at $T=343 \mathrm{~K}$.

Strength and relative elongation at break were determined on the modernized car 2166 P-5 at the clamps spreading speed of $50 \pm 5 \mathrm{~mm} / \mathrm{min}$.

The absorption spectra in the range of 650 $4000 \mathrm{~cm}^{-1}$ were recorded on IR-spectrometer with Tensor37 Fourier Transform by the method of disturbed total internal reflection using a trapezoid prism-crystal diamond (number of reflections $N=1$, the angle $\varphi=39^{\circ}$ ) on the reflection. The assignment of absorption bands was made according to [10].

Amorphous structure of EPU compositions was investigated by the method of wide-angle X-ray diffraction using a DRON-4-07 diffractometer, the X-ray optical scheme was performed under Debye-Scherrer method (by passing the primary beam of radiation through the sample polymer).

Supramolecular structures were investigated by the method of small-angle X-ray scattering using small-angle X-ray RPC-1 cameras with slit collimation of the primary $\mathrm{X}$-ray beam by the Kratki method [11]. Profiles of intensity were normalized by the amount of factor of primary radiation beam weakening by EPU sample and the amount of their scattering volume. X-ray studies were performed in $\mathrm{CuK}_{\alpha}$ radiation, monochromatized by $\mathrm{Ni}-$ filter, at the $T=295 \pm 2 \mathrm{~K}$.

\section{Results and Discussion}

Biodegradation of EPU composites filled with ferrocene were studied by changing their physicalmechanical properties (strength and relative elongation at break) before and after exposure to 199 BM by the methods of IR-spectroscopic and X-ray analysis.

Based on the results of physical-mechanical tests a significant decrease in the values of strength and relative elongation at break for samples of both EPU and EPU composites with ferrocene was observed after 1 month of incubation (Table 1, Fig. 1), which indicates the intense course of biodegradation of these materials under the influence of BM 199. Moreover this process occurs most intensively in EPU not filled with ferrocene.

Introduction of $0.1 \mathrm{wt} \%$ of ferrocene into the composition of the EPU slows this process a bit. Tensile strength after 1 month incubation of EPU $(0.1 \mathrm{~F})$ decreases by $80.1 \%$ (Fig. 1a) compared to the EPU for which a decrease in strength at break is $91.6 \%$. However, during the same period of study EPU compositions with increasing of ferrocene content to $10.0 \mathrm{wt} \%$ biodegrade more intensely in terms of strength characteristics. The decline in strength at break of compositions EPU(10.0F) is $90.7 \%$.

After 3 and 6 months of incubation tensile strength of all the samples increases (compared to 1 month incubation) by $29.7-37.0$ and $38.2-54.7 \%$, respectively, and relative elongation remains constant $(\varepsilon=7 \%)$ (Table 1, Fig. 1). Nonlinear dependence of samples strength on the length of incubation period may be conditioned by redistribution of hydrogen bonds under the influence of BM 199, which leads to the formation of a more ordered structure, and consequently, to a slight increase in strength at break after 3 months of incubation. Considering that the BM 199 is a complex multicomponent biological system, the increase of strength at break after 3 months of incubation also can be explained by the specific interaction of enzyme molecules with urethane groups present in the EPU [12].

According to IR-spectroscopic studies, with the increase in the duration of incubation in BM 199 to 6 months the reduction of intensity of stretching band profile of carbonyl groups of oligoester OOPF $(-\mathrm{C}=\mathrm{C}-\mathrm{COO}-$ ) [13] and urethane fragments of $1727 \mathrm{~cm}^{-1}$, increasing of intensity of the stretching band of carbonyl groups bound into self-associates $\left(v_{\mathrm{C}=\mathrm{O}}\right.$ as. $) 1710 \mathrm{~cm}^{-1}$ and reduction of the intensity of the stretching band of $\mathrm{C}-\mathrm{O}$ ether groups of $1070 \mathrm{~cm}^{-1}$ are observed in the spectra of EPU compositions 
that do not contain ferrocene (Fig. 2). A slight displacement of stretching band of NH- and OH-groups $3395 \mathrm{~cm}^{-1}$ $\left(v_{\mathrm{NH}+\mathrm{OH}}\right)$ towards higher frequency $3410 \mathrm{~cm}^{-1}$ is observed, indicating the occurrence of more free hydrogen bonds $\mathrm{NH}-$ and OH-groups (Fig. 2). There is a redistribution of hydrogen bonds system by hydrolysis of ester and ether bonds, and the emergence of donors and acceptors of protons free of hydrogen bonds and capable to form associates according to trivial biodegradation of polyurethanes [8].

When comparing the IR-spectra of the original EPU (Fig. 2, curve 1) to the compositions containing fer- rocene (Fig. 3, curve 1, Fig. 4, curve 1) the disposition of stretching band of carbonyl group of ester $(-\mathrm{C}=\mathrm{C}-\mathrm{COO}-)$ and urethane fragments $v_{\mathrm{C}=\mathrm{O}} 1727 \mathrm{sm}^{-1}$ to the highfrequency area $1730 \mathrm{~cm}^{-1}$ is observed in the spectra of the $\mathrm{EPU}(0.1 \mathrm{~F})$ and $\mathrm{EPU}(10.0 \mathrm{~F})$. The increase of the intensity of the band $1710 \mathrm{~cm}^{-1}$ is observed, which indicates the occurrence of more associated $\mathrm{C}=\mathrm{O}$ groups and can be explained by the formation of polymer-metal complexes by interacting of oxygen of one carbonyl group OOPF or urethane fragment with the iron atom of ferrocene [14, $15]$.

Table 1

Physical-mechanical properties of EPU compositions after incubation in BM 199

\begin{tabular}{|l|c|c|c|c|c|c|c|c|}
\hline & \multicolumn{2}{|c|}{ control } & \multicolumn{2}{c|}{ 1month } & \multicolumn{2}{c|}{3 months } & \multicolumn{2}{c|}{6 months } \\
\cline { 2 - 9 } & $\sigma, \mathrm{mPa}$ & $\varepsilon, \%$ & $\sigma, \mathrm{mPa}$ & $\varepsilon, \%$ & $\sigma, \mathrm{mPa}$ & $\varepsilon, \%$ & $\sigma, \mathrm{mPa}$ & $\varepsilon, \%$ \\
\hline EPU & 33.65 & 10.4 & 2.83 & 7.0 & 4.49 & 7.0 & 4.58 & 7.0 \\
\hline EPU(0.1F) & 26.93 & 17.2 & 5.36 & 8.0 & 7.63 & 6.7 & 3.86 & 7.0 \\
\hline EPU(3.0F) & 30.03 & 10.5 & 3.82 & 6.0 & 2.26 & 6.5 & 8.44 & 9.0 \\
\hline EPU(10.0F) & 30.43 & 11.5 & 2.83 & 7.0 & 4.08 & 7.0 & 4.58 & 7.0 \\
\hline
\end{tabular}

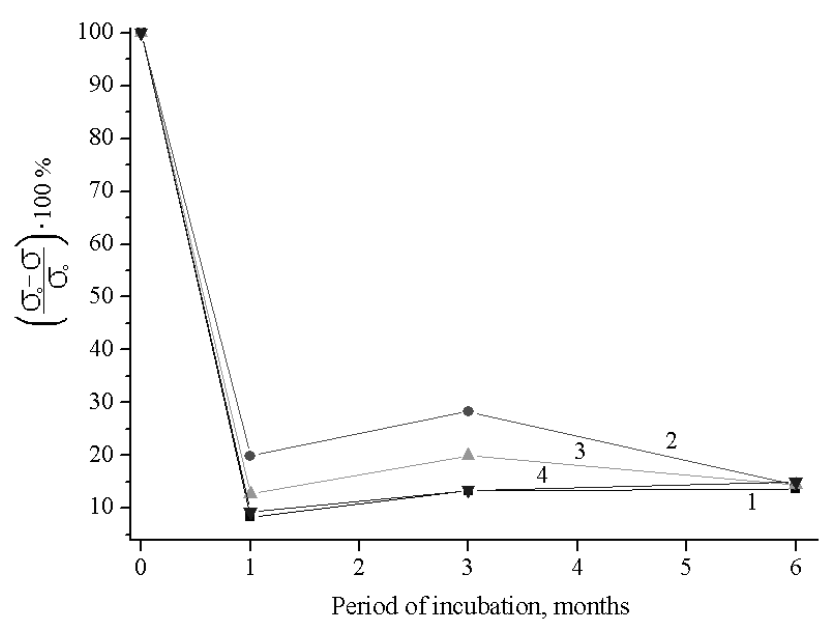

a)

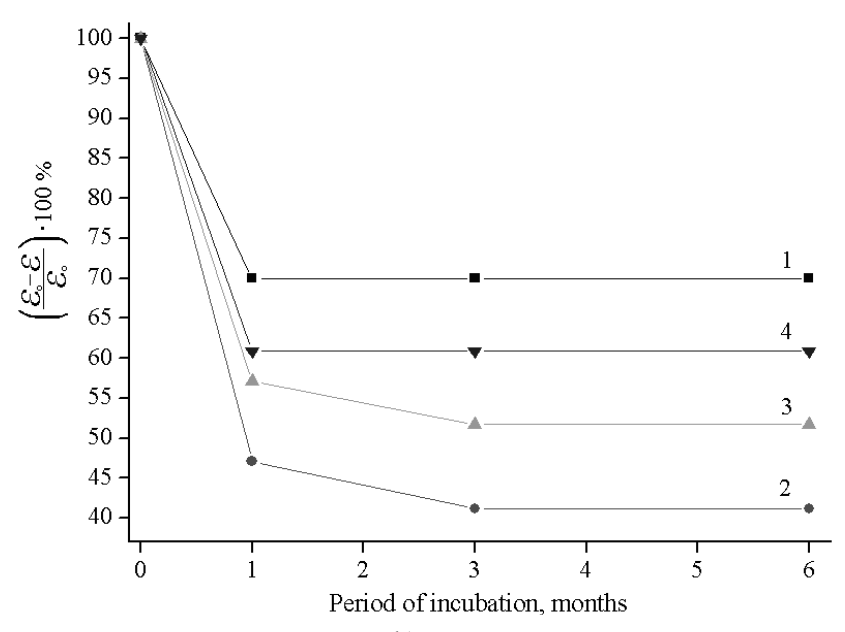

b)

Fig. 1. Percentage dependence of strength (a) and relative elongation at break (b) on the period of incubation: EPU (1); EPU(0.1F) (2); EPU(3.0F) (3) and EPU(10.0F) (4)
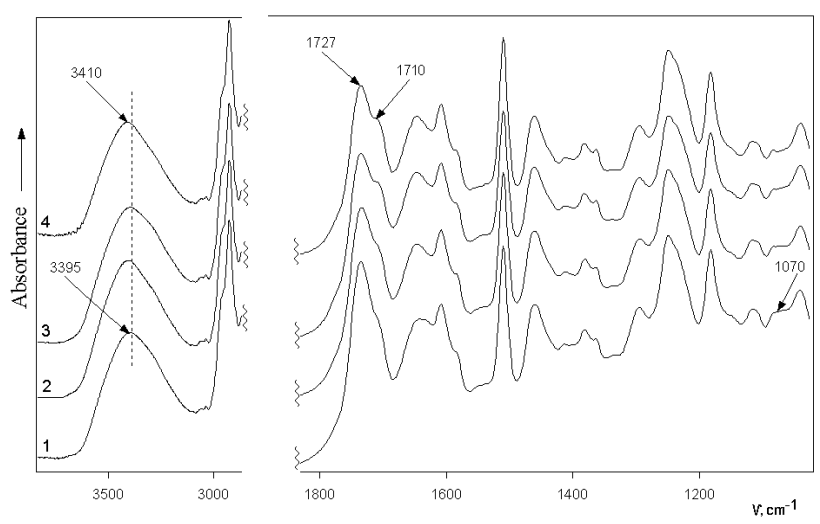

Fig. 2. Fragments of the IR-spectra of EPU before (1) and after incubation in BM 199: 1 (2); 3 (3), and 6 months (4)

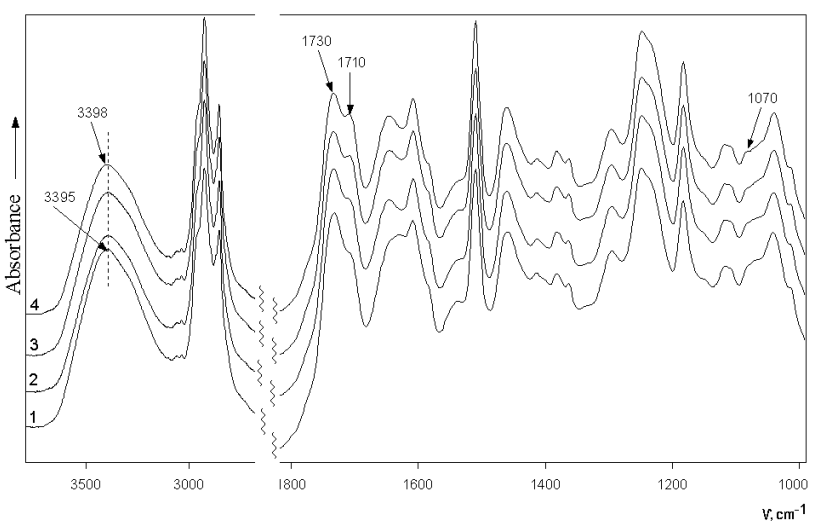

Fig. 3. Fragments of IR-spectra of EPU(0.1F) before (1) and after incubation in BM 199: 1 (2); 3 (3), and 6 months (4) 
The reduction of the intensity of the stretching band of $\mathrm{C}=\mathrm{O}$ groups $1730 \mathrm{~cm}^{-1}$ and an increase in intensity of the band $1710 \mathrm{~cm}^{-1}\left(v_{\mathrm{C}=\mathrm{O} \text { as }}\right)$ is observed in the IR-spectra of $\mathrm{EPU}(0.1 \mathrm{~F})$ after 6 months of incubation (Fig. 3). The intensity of stretching band of $\mathrm{C}-\mathrm{O}$ ether groups $1070 \mathrm{~cm}^{-1}$ decreases (Fig. 3). Compared with the EPU polymer compositions that do not contain ferrocene, the position and intensity of the stretching band of free $\mathrm{NH}-$ and $\mathrm{OH}$-groups $3395 \mathrm{~cm}^{-1}$ varies less $\left(v_{\mathrm{NH}+\mathrm{OH}}\right)$. Its very slight disposition towards higher frequency $3398 \mathrm{~cm}^{-1}$ occurs in BM 199 with the increasing of EPU(0.1F) incubation period (Fig. 3).

Changes in the IR-spectra of $\mathrm{EPU}(10.0 \mathrm{~F})$ are somewhat different from the previous ones. Increase of intensity of the band $v_{\mathrm{C}=\mathrm{O}} 1710 \mathrm{~cm}^{-1}$ and foremost (as compared to the above-described compositions) decrease of intensity of the band $v_{\mathrm{C}-\mathrm{O}} 1070 \mathrm{~cm}^{-1}$ are observed. However, the band of bonds $\mathrm{NH}$ - and $\mathrm{OH}$-groups $3395 \mathrm{~cm}^{-1}$ free of hydrogen remains unchanged (Fig. 4). This can be explained by the formation of metal-polymer complexes between ferrocene iron atoms and polar groups of the polymer matrix.

The calculation of changes of intensities of stretching bands (Table 2) shows that in BM 199 the polymer base biodegrade by ester (decrease of intensity $v_{\mathrm{C}=\mathrm{O}} 1727-1730 \mathrm{~cm}^{-1}$ ) and ether bonds (decrease intensity $v_{\mathrm{C}-\mathrm{O}} 1070 \mathrm{~cm}^{-1}$ ) simultaneously with redistribution of hydrogen bonds (significant increase in the intensity of $v_{\mathrm{C}=\mathrm{O} \text { as. }} 1710 \mathrm{~cm}^{-1}$ for compositions with ferrocene), which is connected with structuring of polymer compositions in BM 199 (increase of the number of molecules connected by intermolecular hydrogen bonds). Biodegradation of source EPU and compositions on its basis with ferrocene takes place more for $\mathrm{C}-\mathrm{O}$ groups of ether links. The decline in the intensity of the band of $v_{\mathrm{C}-\mathrm{O}}$-group $1070 \mathrm{~cm}^{-1}$ after 6 months of incubation ranges from 63 to $98 \%$, while for $v_{\mathrm{C}=\mathrm{O}} 1730 \mathrm{sm}^{-1}$ it is about $14 \%$.

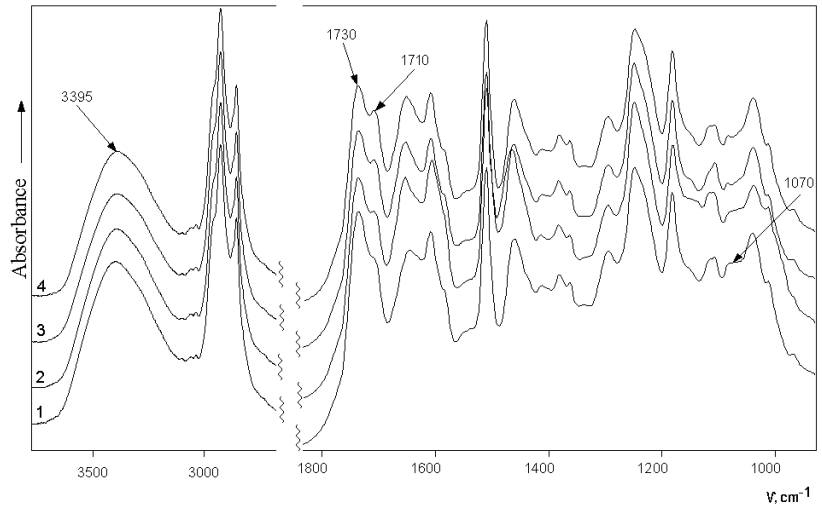

Fig. 4. Fragments of IR-spectra of EPU(10.0F) before (1) and after incubation in BM 199: 1 (2); 3 (3), and 6 months (4)

The analysis of wide-angle X-ray diffractograms of the EPU, which contain in their volume from 0 to $10 \mathrm{wt} \%$ of ferrocene (Fig. 5) revealed that the contents of small additions $(\leq 3 \mathrm{wt} \%)$ of ferrocene does not cause changes in the amorphous structure of the EPU. This is indicated by the same angular position $\left(2 \theta_{\mathrm{m}} \approx 18.6^{\circ}\right)$ of diffraction peak (indicated by the dotted line) of the diffuse type (amorphous ring), which appears on diffractograms of EPU - EPU(3.0F) compositions (curves $1-5)$. With the contents of 5-10 wt \% of ferrocene in the volume of EPU the top of amorphous ring gradually displaces towards $2 \theta_{\mathrm{m}} \approx 18.9^{\circ}$ and $19.3^{\circ}$ with a simultaneous increase in the intensity of scattering angles

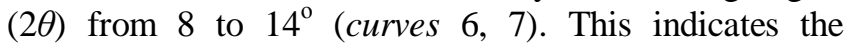
formation of polymer-metal coordination centers between the ferrocene iron atoms and polar (urethane and amide) EPU groups in the volume of EPU [16]. Ferrocene is a low molecular weight crystalline compound. This is, in particular, evidenced by a large number of singlet diffraction peaks of discrete type and multyplex peaks (the most intense is indicated by the arrow) on the X-ray diffraction pattern of ferrocene (curve 8) [17].

Table 2

Changing of intensities of $v_{\mathrm{C}=\mathrm{O}}$ and $v_{\mathrm{C}-\mathrm{o}}$ bands for exposure periods of EPU compositions in vitro

\begin{tabular}{|c|c|c|c|c|c|}
\hline \multirow{2}{*}{ Samples } & \multirow{2}{*}{$\begin{array}{l}\text { Incubation period, } \\
\text { month }\end{array}$} & \multicolumn{4}{|c|}{ Intensity of stretching bands } \\
\hline & & $\mathrm{C}=\mathrm{O}\left(1727 \mathrm{sm}^{-1}\right)$ & $\mathrm{C}=\mathrm{O}\left(1730 \mathrm{sm}^{-1}\right)$ & $\mathrm{C}=\mathrm{O}\left(1710 \mathrm{sm}^{-1}\right)$ & $\mathrm{C}-\mathrm{O}\left(1070 \mathrm{sm}^{-1}\right)$ \\
\hline \multirow{4}{*}{ EPU } & before incubation & 0.5058 & - & 0.0425 & 0.0133 \\
\hline & 1 & 0.4897 & - & 0.0452 & 0.0049 \\
\hline & 3 & 0.4391 & - & 0.0482 & 0.0037 \\
\hline & 6 & 0.4351 & - & 0.0598 & 0.0022 \\
\hline \multirow{4}{*}{$\mathrm{EPU}(0.1 \mathrm{~F})$} & before incubation & - & 0.4668 & 0.0290 & 0.0266 \\
\hline & 1 & - & 0.4421 & 0.0480 & 0.0163 \\
\hline & 3 & - & 0.4215 & 0.0541 & 0.0145 \\
\hline & 6 & - & 0.3998 & 0.0645 & 0.0085 \\
\hline \multirow{4}{*}{$\mathrm{EPU}(10.0 \mathrm{~F})$} & before incubation & - & 0.4933 & 0.0376 & 0.0396 \\
\hline & 1 & - & 0.4483 & 0.0576 & 0.0045 \\
\hline & 3 & - & 0.4251 & 0.0581 & 0.0024 \\
\hline & 6 & - & 0.4251 & 0.0710 & 0.0004 \\
\hline
\end{tabular}


It should be mentioned that the absence of the secondary by intensity diffraction peak in $2 \theta$ from 4 to $8^{\circ}$ in the diffractograms EPU - EPU(3.0F) indicates that epoxy component of EPU is rarely cross-linked.

Taken into account that the metal-complexes are formed in the volume of EPU(10.0F) sample the study of the influence of exposure period of 1 to 6 months in BM 199 on their structure compared to the original EPU was also undertaken.

Based on the analysis of wide-angle X-ray diffraction of EPU sample (not containing ferrocene) before and after incubation in BM 199 for 1, 3, or 6 months (Fig. 6a) we can conclude that after exposure in the model medium amorphous structure of EPU remains unchanged. This is indicated by constant angular position of the amorphous ring $\left(2 \theta_{\mathrm{m}} \approx 18.6^{\circ}\right)$, and, consequently, the same distance between the layers of interstitial molecular units of EPU.

According to small-angle X-ray diffraction (Fig. 6b), the exposure of the EPU sample during 1-6 months in BM 199 invokes only slight disposition of in the interference maximum on the intensity profiles to the area of large scattering angles (from $18.6^{\circ}$ to $18.7^{\circ}$ ), which does not affect the value of the period of $(D \approx 3.8 \mathrm{~nm})$ heterogeneity microareas location in the volume of EPU sample. The estimation of effective size of heterogeneity microareas existing in the sample, exposed in BM 199 was carried out by the Ruland method [18, 19]. It showed that it is a little bigger $\left(l_{p}=2.5 \pm 0.3 \mathrm{~nm}\right)$ than the original sample $\left(l_{p}=2 \pm 0.2 \mathrm{~nm}\right)$.

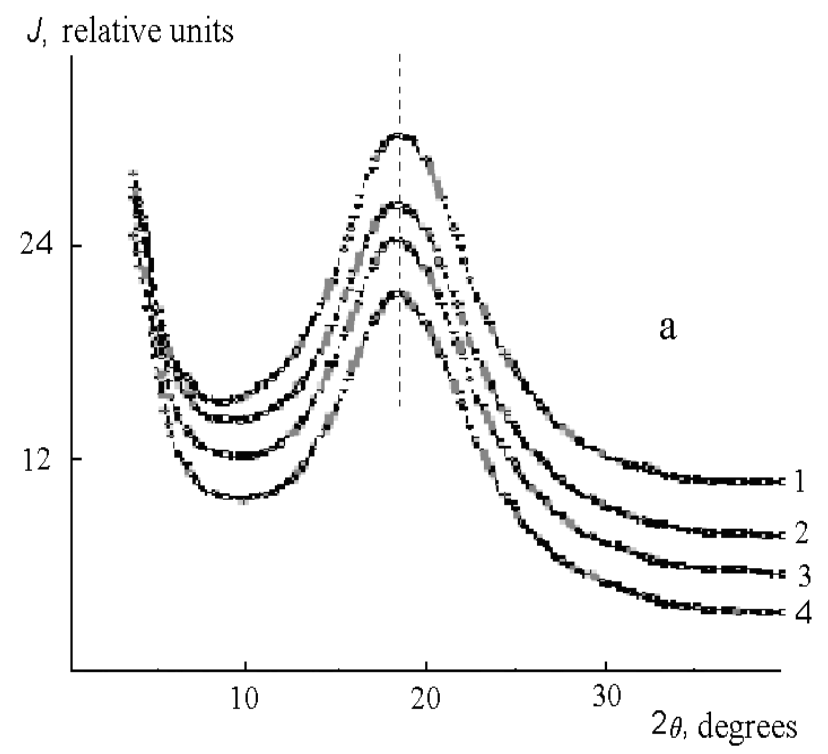

Thus, the analyzes of wide-angle $\mathrm{X}$-ray diffraction sample of EPU(10.0F), both before and after its exposure for 1, 3, or 6 months in BM 199 (Fig. 7), showed that biological medium does not affect close arrangement of fragments of polyurethane macro chains and interstitial molecular component parts of epoxy compositions at their translation in space. This is indicated by the same intensity and angular position $\left(2 \theta_{\mathrm{m}} \approx 18.4\right)$ of amorphous ring in the diffractograms of EPU samples (10.0F).

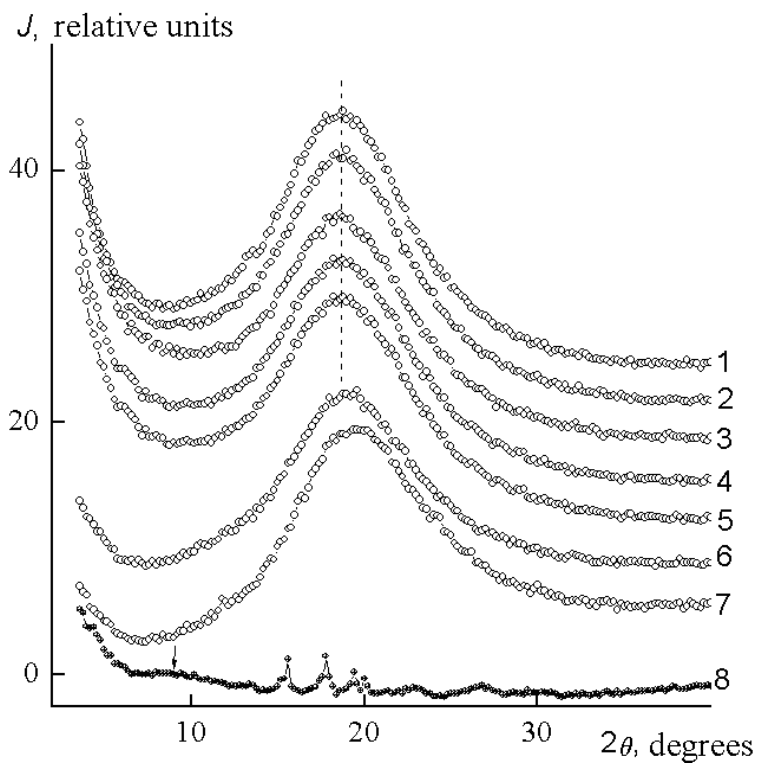

Fig. 5. Wide- angle X-ray diffractions of compositions: EPU (1); EPU(0.1F) (2); EPU(0.5F) (3); EPU(1.0F) (4); EPU(3.0F) (5); $\operatorname{EPU}(5.0 \mathrm{~F})(6) ; \mathrm{EPU}(10.0 \mathrm{~F})(7)$ and ferrocene (8)

$J$, relative units

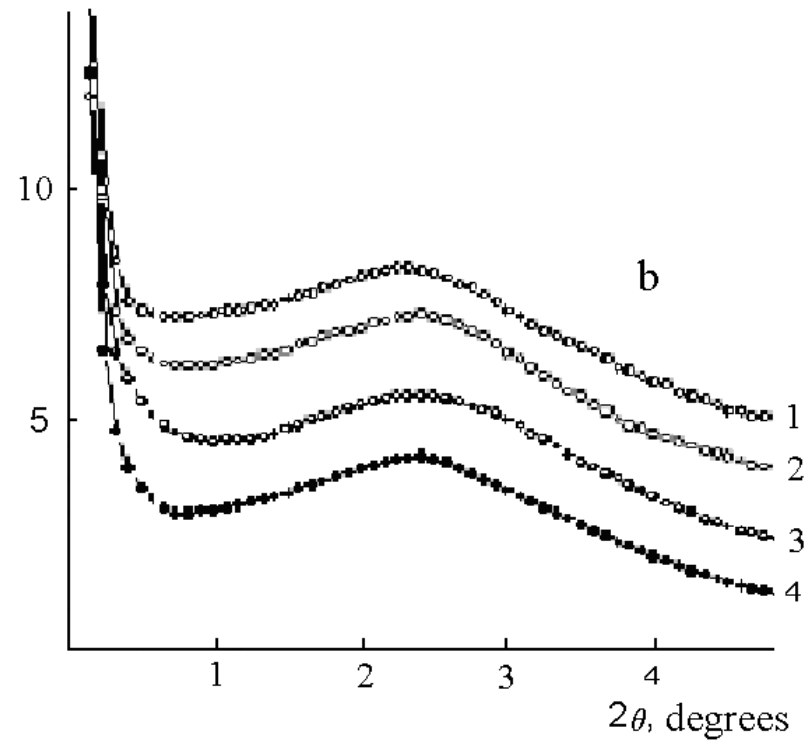

Fig. 6. Wide-angle X-ray diffractogram (a) and profiles of small-angle X-ray scattering of EPU (b) before (1) and after incubation in BM 199: 1 (2); 3 (3), and 6 months (4) 


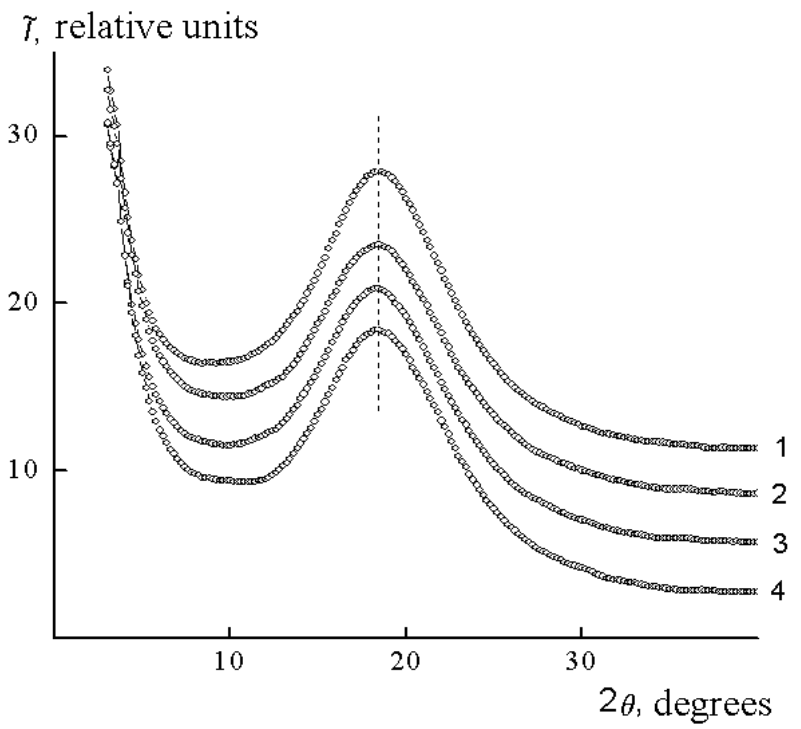

Fig. 7. Wide-angle X-ray EPU diffraction EPU(10.0F) before (1) and after incubation in BM 199: 1 (2); 3 (3), and 6 months (4)

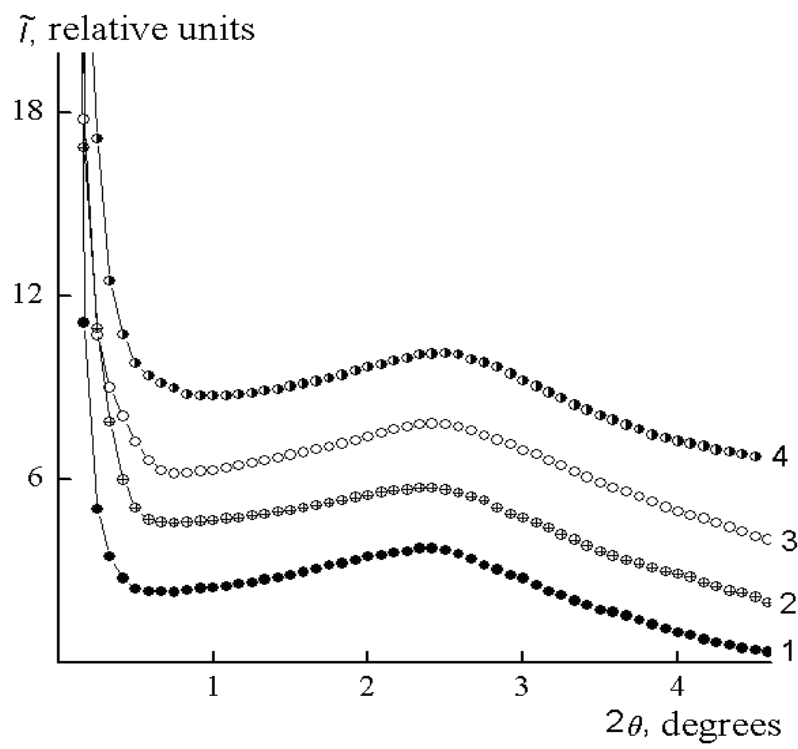

Fig. 8. Profiles of the intensity of small-angle X-ray scattering of EPU(10.0F) before (1) and after incubation in BM 199: 1 (2); 3 (3), and 6 months (4)

Table 3

Parameters of microheterogeneous structure of EPU(10.0F) compositions, exposed in BM 199 for 1 to 6 months

\begin{tabular}{|l|c|c|c|}
\hline \multicolumn{1}{|c|}{ Sample } & $2 \theta_{m}, \mathrm{deg}$ & $D, \mathrm{~nm}$ & $l_{p}, \mathrm{~nm}$ \\
\hline EPU(10.0F)-control & 2.40 & 3.68 & 3.2 \\
\hline EPU(10.0F)-1 month & 2.40 & 3.68 & 3.2 \\
\hline EPU(10.0F)-3 month & 2.45 & 3.60 & 3.4 \\
\hline EPU(10.0F)-6 month & 2.50 & 3.53 & 4.5 \\
\hline
\end{tabular}

Based on the angular position of the amorphous ring, the average distance $(d)$ between layers of polyurethane macro chains and interstitial molecular units of EPU compositions according to the Bragg equation [20]:

$$
d=n \lambda(2 \sin \theta)^{-1}
$$

where: $n$-number of diffraction peak at X-ray diffraction pattern (for polymers assumed that $n=1$, due to the nature of the relaxation processes of structure formation in their volume) is $0.48 \mathrm{~nm}$. As shown in Fig. 7, BM 199 has virtually no effect on the intensity of scattering of X-rays in the range of $2 \theta$ from $10^{\circ}$ to $14^{\circ}$, and, consequently, on the complex formation between ferrocene and polar groups of the sample.

However, when comparing the intensity profiles of small-angle scattering of X-rays of source sample EPU(10.0F) and imposed in BM 199 for 1 to 6 months (Fig. 8) it was revealed that the biological medium somewhat influences the magninude of values in the period $(D)$ of rotation in space of similar in magnitude values of the local electron density $(\rho)$ of heterogeneity microareas.
The data presented in Table 3 shows that the exposure in the BM 199 over 1 month leads to reduction of rotation period in space (in the volume of EPU(10.0F) sample) of similar heterogeneity microareas, which can only be the result of running processes of segregation of rigid and flexible blocks of polyurethane composition component. In this respect, it is important to determine the effective size of similar in magnitude $\rho$ values microareas of heterogeneity. According to the estimate of the magnitude range of heterogeneity values $\left(l_{p}\right)$ by the method of the authors of the research [18], the effective size of heterogeneity microareas in exposure of EPU(10.0F) sample in BM 199 during 3 and especially 6 months gradually increases (Table 3 ) reaching the value bigger by $1.3 \mathrm{~nm}$ than the initial sample and after its exposure in this medium for 1 month. This is consistent with the change in time of $D$ value and is the proof of the relaxation nature of structure formation processes in the volume of polymer systems. However, exposure of EPU(10.0F) sample for 6 months in BM 199 has led to $l p>D$. As is known [16] the $D$ period of rotation in space of similar in magnitude values $\rho$ heterogeneity microareas 
also characterizes the average distance between the centers of the nearest neighbors of microareas. Therefore, the $l_{p}$ value can only be less or equal to the value of $D$, since $l_{p}=D$ characterizes a condition when the same type of microareas touch each other with their edges. Therefore, a significant increase of similar heterogeneity microareas after exposure of the sample to BM 199 for 6 months may be the result of specific interaction of molecules of enzymes comprises by BM 199 with urethane and amide EPU groups, similar in structure to the peptide groups of the protein molecule.

Thus, the studies of initial EPU(10.0F) sample exposed for 1, 3, and 6 months in BM 199 found minor changes in the molecular structure on the molecular as well as supermolecular (nano-sized) levels, which are considered to be the consequence of the relaxation nature of the structure formation processes in polymers. In particular, exposure of the sample for 1 to 6 months in BM 199 hardly changes the Bragg distance between the layers of interstitial molecular links and macro chains of epoxy and polyurethane composition components, respectively, and practically does not change the scattering intensity in the range $2 \theta$ from 10 to $14^{\circ}$, which describes the complex formation between ferrocene and its urethane and amide groups. According to small-angle $\mathrm{X}$-ray diffraction, the exposure of the sample for 1 month in BM 199 does not modify its microheterogeneous structure, while the exposure of the sample for 3 and especially 6 months causes the tendency to the decrease of values of period $D$, as well as the tendency to increase of values of effective size of $l_{p}$ similar heterogeneity microareas. In addition, after 6 months of exposure of EPU(10.0F) sample in the BM 199 there is a case when $l p>\mathrm{D}$, which may be the result of specific interaction of enzymatic system of biological medium with urethane and amide groups of the composite material.

\section{Conclusions}

The studies have revealed that during the incubation of epoxy-polyurethane composite materials with ferrocene in model biological medium the biodegradation processes occur, which are accompanied by changes in the properties and structure of the material. The results of physical-mechanical tests indicate an intensive course of biodegradation of all investigated materials. According to the changes in the values of strength at break of composite materials this process is going most intensively after 1 month of incubation in the modeling medium.

According to IR-spectroscopy in model biological medium the redistribution of hydrogen bonds occurs simultaneously with the biodegradation of polymer base by ester and ether bonds, which is connected with structuring (increased number of molecules linked by intermolecular hydrogen bonds) of polymer compositions in BM 199.

The X-ray diffraction studies of epoxy-polyurethane sample filled with $10.0 \mathrm{wt} \%$ ferrocene, before and after incubation in BM 199 for 1, 3, and 6 months showed minor change at the molecular as well as at the supermolecular levels, which are considered to be a consequence of the relaxation nature of structure formation processes in polymers. According to smallangle X-ray diffraction upon the exposure of EPU(10.0F) sample for 3 and especially 6 months in BM 199 a significant growth of similar heterogeneity microareas is observed, which may result from the interaction of the functional groups of the components of the medium with urethane and amide groups of the composition.

\section{References:}

[1] Galatenko N., Kuksin A., Rozhnova R. and Astapenko O.:

Dopov. Nats. Akad. Nauk Ukrainy, 2007, 3, 142.

[2] Galatenko N., Kuksin A., Astapenko O. and Rozhnova R.: Dekl. Pat. Ukrainy 13318, Publ. March 15, 2006.

[3] Kuksin A., Galatenko N., Rozhnova R. and Astapenko O.: Pat. Ukrainy 79557, Publ. June 25, 2007.

[4] Galatenko N., Kuksin A., Rozhnova R. and Astapenko O..: Polimerny Zh., 2008, 30, 168.

[5] Galatenko N., Rozhnova R. and Gorbunova N.: Pat. Ukrainy 59922, Publ. June 10, 2011.

[6] Rudenchyk T., Rozhnova R., Davidenko V. and Demchenko I.: Polimerny Zh., 2013, 34, 437.

[7] Rudenchyk T., Rozhnova R., Kulesh D. et al.: Plastychna ta Rekonstruktyvna Hirurgiya, 2012, 19, 53.

[8] Phakadze G.: Biodestruktiruemye Polimery. Naukova Dumka, Kyiv 1990.

[9] Willy K.: Biologiya. Mir, Moskwa 1962.

[10] Bellamy L.: Infrakrasnye Spectry Slozhnykh Molekul. Izd-vo Inostranoy Lit., Moskwa 1957.

[11] Kratky O., Pilz I. and Schmitz P.: Colloid Interface Sci., 1966, 21, 24.

[12] Lipatova T. and Phakadze G.: Polimery v Endoprotezirovanii, Naukova Dumka, Kyiv 1983.

[13] Slivkin A.: Funktsionalnuy Analiz Organicheskih Lekarstvenyh Veshestv. Voronezh. Gos. Univ., Voronezh 2007.

[14] Frizen A. and Hursan S.: Bashkirskiy Khim. Zh., 2006, 13, 111.

[15] Frizen A. and Hursan S.: Vestnik Bashkirskoho Univ., 2008, 13, 903.

[16] Shtompel V. and Kercha Yu.: Structura Lineynyh Poliuretanov. Naukova Dumka, Kyiv 2008.

[17] Rozhnova R., Rudenchyk T., Davidenko V. et al.: Vysokomol. Soed., 2014, in press.

[18] Perret R., Ruland W.: Kolloid Zh. - Zh. Polymere, 1971, 247, 835.

[19] Ruland W.: J. Appl. Cryst, 1971, 4, 70.

[20] Guinier A.: Rentgenografiya Cristalov. Teoriya i Praktika. Dunod, Paris 1956. 


\section{ДОСЛІДЖЕННЯ БІОДЕГРАДАЦІї ЕПОКСИПОЛІУРЕТАНОВИХ КОМПОЗИЦЙНИХ МАТЕРІАЛІВ, НАПОВНЕНИХ ФЕРОЦЕНОМ, У МОДЕЛЬНОМУ БІОЛОГІЧНОМУ СЕРЕДОВИЩІ}

Анотація. Фізико-механічними, ІЧ-спектроскопічними та рентгеноструктурними методами досліджено вплив модельного біологічного середовища на властивості і структуру епоксиполіуретанових (ЕПУ) композииій з фероиеном. Встановлено, щчо ЕПУ композичї найбільш інтенсивно біодеградують через 1 місяиьь інкубаиії, щчо супроводжується спадом міиності при розриві на 80-92 \%. За результатами ІЧ-спектроскопічних досліджень біодеградація відбувається за естер- ними та більшою мірою етерними зв'язками з одночасним перерозподілом системи водневих зв'язків, що пов'язано зі структуруванням полімерних композичій у модельному біологічному середовищі 199 (БС 199). Підтверджено релаксаиійний характер процесів структуроутворення в об'ємі полімерних композицій під впливом БС 199. За даними малокутової рентгенографії при витримуванні зразка ЕПУ(10.0Ф) 6 місячув у БС 199 спостерігається зростання однотипних мікрообластей гетерогенності, щуо може бути наслідком специфічної взаємодії молекул ферментів, які входять до складу БС 199, з уретановими та амідними групами ЕПУ.

Ключові слова: епоксиполіуретан, композиційні матеріали, фероиен, біодеградаиія. 